Syntaxe des langues indo-iraniennes anciennes: colloque international, Sitges (Barcelona), 4-5 mai 1993 / organisé par l'Institut du proche-Orient ancien (Université de Barcelone) ; actes éd. par É. Pirart, Sabadell, Ed. Ausa, 1997, 220 p., bibliographie à la fin des articles ou notes bibliogr. (Aula Orientalis, Supplementa ; 6).

\title{
Vincent Hachard
}

\section{(2) OpenEdition \\ Journals}

Édition électronique

URL : http://journals.openedition.org/abstractairanica/34221

DOI : 10.4000/abstractairanica.34221

ISSN : 1961-960X

Éditeur :

CNRS (UMR 7528 Mondes iraniens et indiens), Éditions de l'IFRI

Édition imprimée

Date de publication : 15 mai 2003

ISSN : 0240-8910

Référence électronique

Vincent Hachard, «Syntaxe des langues indo-iraniennes anciennes : colloque international, Sitges (Barcelona), 4-5 mai 1993 / organisé par l'Institut du proche-Orient ancien (Université de Barcelone) ; actes éd. par É. Pirart, Sabadell, Ed. Ausa, 1997, 220 p., bibliographie à la fin des articles ou notes bibliogr. (Aula Orientalis, Supplementa ; 6). », Abstracta Iranica [En ligne], Volume 24 | 2003, document 27, mis en ligne le 05 janvier 2010, consulté le 25 septembre 2020. URL : http:// journals.openedition.org/abstractairanica/34221 ; DOI : https://doi.org/10.4000/abstractairanica. 34221

Ce document a été généré automatiquement le 25 septembre 2020.

Tous droits réservés 
Syntaxe des langues indo-iraniennes anciennes: colloque international, Sitges (Barcelona), 4-5 mai 1993 / organisé par l'Institut du procheOrient ancien (Université de Barcelone) ; actes éd. par É. Pirart, Sabadell, Ed. Ausa, 1997, 220 p., bibliographie à la fin des articles ou notes bibliogr. (Aula Orientalis, Supplementa;6).

Vincent Hachard

Sur les 12 communications publiées dans ce recueil, 5 sont consacrées aux langues irano-aryennes (avestique, vieux perse et moyen perse), et une à l'indo-iranien. Ce sont: Almut Hintze, «Parataxis and hypotaxis in the Avesta », pp. 51-62 ; Jean Kellens, "Les fonctions du génitif en vieil-avestique», pp. 81-90; Antonio Panaino, "Considération on the "mixed fractions" in Avestan", pp.91-109; Éric Pirart, "Avestique him», pp.143-160; Prods Oktor Skjærvø, "On the Middle Persian imperfect", pp.161-188 (avec planches) et Calvert Watkins, " "Throng-lord of throngs": an Indo-Iranian stylistic figure », pp. 215-220. 
INDEX

Thèmes : 2.2. Langues vivantes et dialectes

\section{AUTEURS}

VINCENT HACHARD

BIULO - Paris 